\title{
Article
}

\section{Implementasi Peraturan Bupati Merangin Nomor 12 Tahun 2016 Tentang Sistem Pengendalian Kebakaran Hutan dan Lahan Dalam Pembukaan Lahan Perkebunan di Desa Seling Kecamatan Tabir Kabupaten Merangin Provinsi Jambi Tahun 2017}

\author{
Harpin Syah ${ }^{1 *}$, Eko Aprio ${ }^{2}$
}

This article is an open access article distributed under the terms and conditions of the Creative Commons Attribution-ShareAlike 4.0 International (CC BY SA ) License (https://creativecommo ns.org/licenses/by$\mathrm{sa} / 4.0 /$ ).

Jurnal Politik dan Pemerintahan Daerah ISSN 2686-2271

Fakultas Ilmu Sosial dan Ilmu Politik, Universitas Muara Bungo Jl. Diponegoro No. 27, Muara Bungo-Jambi, (0747) 323310
${ }^{1}$ Program Studi Ilmu Pemerintahan Fakultas Ilmu Sosial Dan Ilmu Politik, Universitas Muara Bungo, Kabupaten Bungo, Provinsi Jambi

2 Program Studi Ilmu Pemerintahan Fakultas Ilmu Sosial Dan Ilmu Politik, Universitas Muara Bungo, Kabupaten Bungo, Provinsi Jambi

* Correspondence Author: Harpinsyah7@gmail.com

Abstract: The forest and land fires that occurred in Seling Village were caused by the clearing of new land for plantations, as well as the opening of farming areas by the community. The purpose of this study was to determine the implementation of Merangin Regent Regulation No. 12 of 2016 concerning Forest and Land Fire Control System in the clearing of plantation land in Seling Village, Tabir District, Merangin Regency and to find out the obstacles in implementing Merangin Regent's Regulation No. 12 of 2016 concerning Control System. Forest and Land Fires in Seling Village, Tabir District, Merangin Regency. The method used in this study is a qualitative research method with a descriptive study. The method used in this study is a qualitative research method with a descriptive study. The informant selection technique used by the researcher in this research is to use the purposive sampling method (the technique of determining the sample with certain considerations). The results of this study indicate that the implementation of the Merangin Regent Regulation Number 12 of 2016 concerning the Forest and Land Fire Control System has not been fully implemented, where the provisions that have been set have not been fulfilled including the organizational structure and control procedures, forest and land fire prevention, forest and land fire prevention, handling after forest and land fires, increasing public awareness of the application. Obstacles in implementing Merangin Regent Regulation Number 12 of 2016 concerning Forest and Land Fire Control Systems in Seling Village Tabir District, Merangin Regency, among others, are low public awareness and the high cost of clearing land with heavy equipment.

Keywords: Implementation, Regional Regulation No. 12/2016, Plantation Land Clearing

Abstrak: Kebakaran hutan dan lahan yang terjadi di Desa Seling disebabkan oleh pembukaan lahan baru untuk perkebunan, serta pembukaan areal perladangan oleh masyarakat. Tujuan penelitian ini adalah untuk mengetahui implementasi Peraturan Bupati Merangin Nomor 12 Tahun 2016 Tentang Sistem Pengendalian Kebakaran Hutan dan Lahan dalam pembukaan lahan perkebunan di Desa Seling Kecamatan Tabir Kabupaten Merangin dan untuk mengetahui hambatan-hambatan dalam implementasi Peraturan Bupati Merangin Nomor 12 Tahun 2016 Tentang Sistem Pengendalian Kebakaran Hutan dan Lahan di Desa Seling Kecamatan Tabir Kabupaten Merangin. Metode yang digunakan dalam penelitian ini penelitian ini adalah metode penelitian kualitatif yang bersifat dengan studi deskriptif. Metode yang digunakan dalam penelitian ini penelitian ini adalah metode penelitian kualitatif yang bersifat dengan 
studi deskriptif. Teknik pemilihan informan yang digunakan oleh peneliti dalam penelitian ini adalah dengan menggunakan metode purposive sampling (teknik penentuan sampel dengan pertimbangan tertentu). Hasil penelitian ini menunjukkan bahwa implementasi Peraturan Bupati Merangin Nomor 12 Tahun 2016 Tentang Sistem Pengendalian Kebakaran Hutan dan Lahan belum sepenuhnya diterapkan, dimana belum terpenuhinya ketentuan yang teah ditetapkan diantaranya struktur organisasi dan prosedur pengendalian, pencegahan kebakaran hutan dan lahan, penanggulangan kebakaran hutan dan lahan, penanganan pasca kebakaran hutan dan lahan, peningkatan kesadaran masyarakat penerapan. Hambatan-hambatan dalam implementasi Peraturan Bupati Merangin Nomor 12 Tahun 2016 Tentang Sistem Pengendalian Kebakaran Hutan dan Lahan di Desa Seling Kecamatan Tabir Kabupaten Merangin diantaranya adalah rendahnya kesadaran masyarakat dan mahalnya biaya buka lahan dengan alat berat

Kata Kunci: Implementasi, Perda No.12/2016, Pembukaan Lahan Perkebunan

\section{Pendahuluan}

Indonesia merupakan salah satu Negara tropis yang memiliki wilayah hutan terluas di dunia setelah Brazil dan Zaire. Hal ini merupakan suatu kebanggaan bagi bangsa Indonesia, karena dilihat dari manfaatnya sebagai paru-paru dunia, pengatur aliran air, pencegah erosi dan banjir serta dapat menjaga kesuburan tanah. Selain itu, hutan dapat memberikan manfaat ekonomis sebagai penyumbang devisa bagi kelangsungan pembangunan di Indonesia. Karena itu pemanfaatan hutan dan perlindungannya telah diatur dalam UUD 45, Undang-Undang Nomor 41 tahun 1999 tentang Kehutanan, PERPU Nomor 1 Tahun 2004 tentang Perubahan Atas UU Nomor 41 tentang Kehutanan, Undang-Undang Nomor 19 Tahun 2014 tentang Penetapan PERPU Nomor 1 Tahun 2004 tentang Perubahan Atas UU Nomor 41 tentang Kehutanan Menjadi Undang-Undang, Undang-Undang Nomor 18 Tahun 2003 tentangPencegahan dan Pemberantasan Perusakan Hutan, Undang - Undang Nomor 32 Tahun 2009 tentang Perlindungan dan Pengelolaan Lingkungan Hidup. Dampak dari kebakaran hutan ini adalah manusia dapat kehilangan potensi dan manfaat hutan yang digunakan dalam pemenuhan kebutuhan sehari-hari seperti bahan bangunan, bahan makanan, dan obat obatan serta kehilangan udara bersih dan hilangnya fungsi hutan sebagai pengatur tata air dan pencegah erosi (Rasyid, 2014).

Di Indonesia, kesadaran untuk merawat hutan masih kurang, padalah kesehatan hutan merupakan upaya untuk mengendalikan hutan dan mempertahankan hajat hidup manusia (Safe'i et al., 2019). Oleh karena itu, pemerintah telah membentuk Pusat Pengendalian Kebakaran Hutan dan Lahan (Pusdalkarhutla) dan Satuan Pelaksana Pengendalian Kebakaran Hutan dan Lahan(Satlakdalkarhutla) maupun tim koordinasi nasional pengendalian kebakaran hutan dan lahan dan sekarang menjadi Badan Nasional Pengendalian (BNPB) Badan Penanggulangan Bencana Daerah (BPBD). Namun sulit sekali dilaksanakan. Sekalipun disadari kebakaran hutan selalu berulang, namun tingkat kewaspadaan aparat khususnya di daerah, terkesan sangat kurang. Pemerintah baru bergegas melakukan tindakan bahkan terlihat panik bila kebakaran sudah mulai terjadi, kemudian menurun apabila kebakaran sudah dapat di atasi. Semestinya, kewaspadaan tetap tinggi setidaknya mengikuti indikator titikapi dari hasil pemantauan satelit.

Kebakaran hutan dan lahan di Provinsi Jambi hampir setiap tahun terjadi, wilayah yang kebakran biasanya terjadi pada musim kemarau, di Provinsi Jambi 
lahan yang paling luas terbakar adalah lahan gambut, mayoritas terjadi pada areal konsensi perusahaan perkebunan kelapa sawit dan hutan tanaman industri yang berproduksi di atas lahan gambut. Walhi Jambi sendiri memastikan $80 \%$ titik api berada sebaran titik api berada di izin HTI dan sawit ( http//:www.walhijambi.com.2016)

Tabel 1. Luas Hutan dan Lahan Terbakar Provinsi Jambi 2011-2015

\begin{tabular}{l|l|l} 
No & Tahun & Luas /Hektar \\
1 & 2011 & 89,00 \\
2 & 2012 & 11,22 \\
3 & 2013 & 199,10 \\
4 & 2014 & $3.470,61$ \\
5 & 2015 & $19.528,00$
\end{tabular}

Berdasarkan tabel di atas terlihat jelas bahwa terjadinya peningkatakan kebakaran hutan setiap tahunnya. Dimana pada tahun 2011 hanya seluas 89 hektar namun melonjak hingga $21.941 \%$ atau seluas 19.528 hektar. Kebakaran hutan dan lahan yang menyebabkan bencana asap tersebut dipengaruhi oleh berbagai faktor. Berdasarkan data BNPB (2013) kebakaran disebabkan oleh dua faktor utama, yaitu kebakaran didukung oleh pemanasan global, kemarau ekstrim yang seringkali dikaitkan dengan pengaruh iklim yang memberikan kondisi ideal untuk terjadinya kebakaran hutandan aktivitas manusia dalam pengelolaan lahan. Persentase yang berasal dari kegiatan manusia sebanyak 99\%, baik disengaja maupun karena unsur kelalaian. Kebakaran lahan yang terjadi akibat pengaruh iklim hanya terjadi sebagian kecil (Sri Nurhayati, 2014).

Motif kebakaran lahan yang disebabkan aktivitas manusia tersebut atas pertimbangan aspek ekonomi, budaya dan sosial. Aspek ekonomi yakni alasan yang dikemukakan bahwa pembukaan lahan dengan membakar merupakan cara yang paling mudah, murah serta lebih efektif. Aspek budaya, dulu kebiasaan masyarakat Jambi juga membuka lahan dengan cara membakar, akan tetapi api tidak sampai merambat, karena gambut masih relatif basah dan tentunya pada saat pembakaran juga dijaga dan pola yang dipakai masyarakat pada saat melakukan pembakaran juga berbeda, hanya kayu dan dahan yang kering sajalah yang dibakar. Aspek sosial, kepedulian masyarakat setempat tergolong rendah, karena mereka menaganggap bahwa jika terjadi kebakaran dan merambat ke lahan mereka maka lahan akan menjadi luas tidak perlu mereka membuka lahan sendiri (Asnawi, 2016).

Pemerintah Kabupaten Merangin telah mengeluarkan Peraturan Bupati Merangin Nomor 12 Tahun 2016 Tentang Sistem Pengendalian Kebakaran Hutan dan Lahan yang dengan tegas telah melarang membakar hutan dan lahan baik secara perorang maupun dilakukan oleh perusahaan perkebunan yang memiliki badan hukum.

Desa Seling merupakan salah satu desa dalam Kecamatan Tabir Kabupaten Merangin yang memiliki perkebunan karet yang cukup luas, dimana masyarakatnya menjadikan kebun karet sebagai matapencaharian mereka. Umumnya masyarakat Desa Seling memiliki kebun karet setiap kepala keluarga, baik yang ditanami sendiri maupun warisan dari orang tua mereka. Saat membuka lahan perkebunan karet tersebut, masyarakat pada umumnya melakukan pembakaran terhadap hutan yang telah mereka buka (tebang pohonnya), meskipun telah dilakukan berbagai macam sosialisasi dan peringatan oleh pemerintah desa dan kecamatan hingga pemerintah Kabupaten Merangin dengan mengandeng Koramil Tabir, namun pembakaran lahan perkebunan sering dilakukan masyarakat pada sore hari menjalang senja. Merujuk pada Peraturan Bupati Merangin Nomor 12 Tahun 2016 Tentang Sistem Pengendalian Kebakaran Hutan dan Lahan Pasal 2 huruf "e" disebutkan bahwa ruang lingkup pengendalian kebakaran hutan dan lahan termasuk meningkatkan penegakan dan memberikan sanksi yang tegas 
terhadap perorangan atau badan hukum yang terlibat dengan kegiatan pembakaran hutan dan lahan. Hanya saja hingga sekarang belum ada sanksi tegas yang diberikan kepada masyarakat yang membakar hutan tersebut.

Berdasarkan data yang diperoleh pada Badan Penanggulangan Bencana Daerah Kabupaten Merangin diketahui bahwa Desa Seling selama tahun 2017 terdapat 2 (dua) titik hotspot pada Bulan Oktober 2017. Hal ini sebagaimana terlihat pada tabel di bawah ini:

Tabel 2. Inventarisasi Titik Hotspot yang Muncul Berdasarkan Informasi/ Publikasi BMKG dan Disbunhut Provinsi Jambi Tahun 2017

\begin{tabular}{|c|c|c|c|c|c|c|}
\hline No & Bulan & Tgl & $\begin{array}{c}\text { Titik } \\
\text { Hotspot }\end{array}$ & Kecamatan & Desa/Kelurahan & Satelit \\
\hline 1 & Juni & 5 & 2 & Jangkat & Beringin Tinggi & Lapan \\
\hline 2 & & 5 & 2 & Sungai Manau & & Lapan \\
\hline 3 & Juni & 7 & 2 & Jangkat & & Lapan \\
\hline 4 & & 7 & 2 & Muara Siau & Tiang Pumpung & Lapan \\
\hline 5 & Juni & 2 & 1 & Bangko & & Lapan \\
\hline 6 & Agustus & 4 & 1 & Lbh. Masurai & Desa Rancan & Lapan \\
\hline 7 & & 4 & 2 & Tiang Pumpung & Beringin Sanggul & Lapan \\
\hline 8 & & 26 & 1 & Tabir Ilir & & Lapan \\
\hline 9 & & 27 & 1 & Lbh. Masurai & Desa Rancan & Lapan \\
\hline 10 & & 27 & 1 & Tiang Pumpung & & Lapan \\
\hline 11 & September & 12 & 1 & Nalo Tantan & Nalo Gedang & Lapan \\
\hline 12 & September & 13 & 1 & Tabir Barat & Sungai Tabir & Lapan \\
\hline 13 & September & 12 & 1 & Muara Siau & Lubuk Birah & Lapan \\
\hline 14 & September & 16 & 1 & $\begin{array}{l}\text { Pamenang } \\
\text { Selatan }\end{array}$ & Tanjung Beruang & Lapan \\
\hline 15 & Oktober & 16 & 1 & Bangko Barat & Biuku Tanjung & Lapan \\
\hline 16 & Oktober & 18 & 4 & Bangko & Langling & Lapan \\
\hline 17 & & & & Jangkat & & Lapan \\
\hline 18 & & & & Nalo Tantan & Nalo Gedang & Lapan \\
\hline 19 & & & & Tabir Ilir & & Lapan \\
\hline 20 & Oktober & 19 & 2 & $\begin{array}{c}\text { Tabir } \\
\text {. }\end{array}$ & Seling & Lapan \\
\hline $\begin{array}{l}21 \\
22\end{array}$ & & & & Jangkat Timur & & $\begin{array}{l}\text { Lapan } \\
\text { Lapan }\end{array}$ \\
\hline $\begin{array}{l}22 \\
23\end{array}$ & $\begin{array}{l}\text { Oktober } \\
\text { Oktober }\end{array}$ & $\begin{array}{l}2 L \\
25\end{array}$ & $\begin{array}{l}1 \\
2\end{array}$ & $\begin{array}{c}\text { Tabir } \\
\text { Lbh. Masurai }\end{array}$ & $\begin{array}{l}\text { Seling } \\
\text { Muara Pangi }\end{array}$ & $\begin{array}{l}\text { Lapan } \\
\text { Lapan }\end{array}$ \\
\hline 24 & & & & Jangkat Timur & Desa Kabu & Lapan \\
\hline 25 & Oktober & 26 & 1 & Muara Siau & & Lapan \\
\hline 26 & Oktober & 29 & 1 & Jangkat & & Lapan \\
\hline 27 & Desember & 6 & 1 & Tiang Pumpung & Sekancing & Lapan \\
\hline
\end{tabular}

Sumber : BPBD Kabupaten Merangin, 2018

Berdasarkan wawancara awal peneliti dengan beberapa masyarakat Desa Seling diketahui bahwa alasan klasik yang dikemukan oleh masyarakat desa Seling saat membuka lahan perkebunan baru dengan cara membakar adalah biaya atau ongkos pembukaan lahan menggunakan alat berat sangatlah mahal, dengan cara membakar tersebut masyarakat dapat menekan biaya pembukaan lahan perkebunan.

Hasil dari observasi awal peneliti di Desa Seling didapatkan bahwa terdapat beberapa permasalahan dalam Implementasi Peraturan Bupati Merangin Nomor 12 Tahun 2016 Tentang Sistem Pengendalian Kebakaran Hutan Dan Lahan Dalam Pembukaan Lahan Perkebunan, diantaranya adalah belum terbentuknya Regu Dalkarhutla tingkat desa Seling, minimnya sosialisasi yang dilakukan oleh Satgas Darkarhutla Kecamatan Tabir, kurang aktifnya pengawasan yang dilakukan oleh Satgas Darkarhutla Kecamatan Tabir, masih banyak pelaku pembakaran hutan yang dilindungi oleh Kepala Desa beserta perangkatnya, serta rendahnya partisipasi masyarakat Desa Seling dalam hal pencegahan dan pengendalian kebakaran hutan. 
Bila kondisi ini dibiarkan maka akan mempengaruhi keberlanjutan ekosistem di Desa Seling. Tercapainya tujuan terhadap pencegahan dan pengendalian kebakaran hutan dan lahan yang dilakukan oleh pemerintah tidak terlepas dari peran pemerintah daerah. Berdasarkan femonema tersebut peneliti tertarik untuk melakukan penelitian dengan judul "Implementasi Peraturan Bupati Merangin Nomor 12 Tahun 2016 Tentang Sistem Pengendalian Kebakaran Hutan Dan Lahan Dalam Pembukaan Lahan Perkebunan Desa Seling Kecamatan Tabir Kabupaten Merangin Tahun 2017.

Pembahasan

Implementasi Peraturan Bupati Merangin Nomor 12 Tahun 2016 Tentang Sistem Pengendalian Kebakaran Hutan dan Lahan dalam Pembukaan Lahan Perkebunan di Desa Seling Kecamatan Tabir Kabupaten Merangin

\section{Belum Terbentuknya Regu Darkarhutla}

Kebakaran hutan dan lahan yang terjadi di Desa Seling disebabkan oleh pembukaan lahan baru untuk perkebunan, serta pembukaan areal perladangan oleh kelompok masyarakat di Desa Seling Kecamatan Tabir Kabupaten Merangin.

Berdasarkan Pasal 3 Peraturan Bupati Merangin Nomor 12 Tahun 2016 Tentang Sistem Pengendalian Kebakaran Hutan dan Lahan dinyatakan bahwa organisasi pengendalian kebakaran hutan dan lahan (Darkarhutla) terdiri dari:
a. Satgas Darkarhutla Kabupaten
b. Satgas Darkarhutla Kecamatan
c. Regu Darkarhutla Desa/Kelurahan

Struktur organisasi pengendalian kebakaran hutan dan lahan (Darkarhutla) belum sepenuhnya terbentuk, hal dikarenakan belum dibentukannya Regu Darkarhutla di Desa Seling. Regu Darkarhutla di Desa Seling belum terbentuk dikarenakan keterbatasan dana, padahal Ayat 4 Pasal 3 menjelaskan bahwa sebagai koordinator Regu Darkarhutla Desa adalah kepala desa atau pejabat kepala desa. Kemudian pada Pasal 5 dijelaskan bahwa keanggotaan Regu Darkarhutla Desa terdiri dari unsur Perangkat Desa, BPD, Pemuda dan Tokoh Masyarakat, dengan kondisi tersebut sebenarnya Regu Darkarhutla Desa Seling dapat terbentuk dikarenakan keanggotaanya sudah ada, tinggal membentuk timnya saja lagi.

2. Pencegahan Kebakaran Hutan dan Lahan

Berdasarkan Pasal 15 Peraturan Bupati Merangin Nomor 12 Tahun 2016 Tentang Sistem Pengendalian Kebakaran Hutan dan Lahan dinyatakan bahwa setiap orang dan/atau badan hukum dilarang membakar hutan dan lahan, pelaksanaan pembakaran lahan untuk tujuan khusus dapat dilakukan setelah memperoleh izin dari pejabat yang berwenang. Kondisi masyarakat Desa Seling yang tidak mengindahkan himbauan yang dilakukan oleh Kepala Desa Seling berkenaan dengan pelarangan membuka lahan untuk perkebunan dengan cara membakar hutan karena berdampak terhadap lingkungan.

Pernyataan tersebut menggambarkan kondisi hutan di Indonesia, Kebakaran hutan dan lahan di Indonesia meningkat selama sepuluh tahun terakhir ini, sebagian besar disebabkan oleh ulah manusia (yang disengaja atau karena lalai) juga karena kondisi yang sangat kering sebagai pengaruh terjadinya perubahan iklim global/makro yang melanda wilayah Indonesia. Kebakaran hutan menjadi ancaman tersendiri bagi negara yang bersangkutan maupun dunia secara umum. Telah dipahami bahwa hutan memegang peranan yang penting bagi keseimbangan hidup di bumi. Rusaknya hutan akan berdampak pada keberlangsungan semua makhluk hidup termasuk manusia. Oleh sebab itu, kelestarian hutan bukanlah sebuah pilihan tetapi sebuah 
keharusan. Angka statistik menunjukkan adanya fakta bahwa areal hutan hari demi hari semakin berkurang. Salah satu penyebabnya adalah kebakaran, baik itu yang terjadi secara alamiah maupun karena ulah manusia yang sedang membuka hutan/lahan untuk usaha pertanian ataupun perkebunan. Langkah penanggulangan kerusakan dan kebakaran hutan tentunya jangan membuka lahan/hutan untuk keperluan pertanian/perkebunan dengan cara dibakar. Bila hal ini tetap dilakukan bukan hal yang tak mungkin kelak bumi bukan lagi planet yang nyaman untuk dihuni manusia tetapi menjadi bumi yang panas membara.

Terdapat cara lain bagi masyarakat jika ingin membuat perkebunan karet atau sawit tanpa harus membakar lahan. Apabila hal tersebut dapat dilaksanakan tentunya akan berdampak positif terhadap ekosistem alam. Beberapa manfaat pembukaan lahan tanpa pembakaran adalah: 1) tidak menimbulkan polusi asap; 2) menurunkan emisi gas rumah kaca (terutama CO2) yang berdampak negatif pada perubahan iklim yang berpengaruh pada stabilitas ekosistem, aktifitas transportasi, komunikasi dan kesehatan manusia; 3) memperbaiki bahan organik tanah, kadar air dan kesuburan tanah terutama di areal yang sudah pernah ditanami sehingga menurunkan kebutuhan pupuk organik; 4) dalam jangka panjang pembukaan lahan tanpa pembakaran akan menjamin kesinambungan secara ekonomi dan ekologi; 5) untuk mengantisipasi kemungkinan terjadinya kekeringan yang akan berdampak langsung kepada produksi tanaman, akibatnya hasil panen akan mengalami penurunan; dan 6) untuk pemulihan kualitas lingkungan yang berbasis pembangunan berkelanjutan.

Kondisi masyarakat yang tidak peduli terhadap hutan dan lingkungan. Hutan dan lahan merupakan sumberdaya alam yang bila dikelola dengan baik dan benar akan sangat bermanfaat bagi pembangunan nasional khususnya pelestarian lingkungan. Namun demikian pengelolaan hutan dan lahan sering diabaikan yang mengakibatkan terjadinya bencana dan gangguan seperti kebakaran hutan, banjir dan tanah longsor sehingga merusak lingkungan, menurunkan produksi dan menghambat pelestariannya.

Pembakaran lahan yang dilakukan masyarakat dalam rangka membuka kebun karet berpotensi menimbulkan kebakaran hutan yang lebih besar, apalagi jiak tidak dilakukan pengendalian, sehingga kegiatan tersebut bertentangan dengan Pasal 16 Peraturan Bupati Merangin Nomor 12 Tahun 2016 Tentang Sistem Pengendalian Kebakaran Hutan dan Lahan menyatakan bahwa setiap orang atau badan hukum dilarang dengan sengaja atau tidak sengaja melakukan tindakan yang dapat menyebabkan terjadinya kebakaran hutan dan lahan yang mengakibatkan vegetasi terbakar dan meluas ke lahan dan atau hutan sekitarnya.

Pengedalian kebakaran hutan juga harus dilakukan oleh masyarakat, sebagaimana dinyatakan dalam Pasal 17 Peraturan Bupati Merangin Nomor 12 Tahun 2016 Tentang Sistem Pengendalian Kebakaran Hutan dan Lahan yang berbunyi bahwa masyarakat disekitar hutan dan lahan yang rawan kebakaran mempunyai kewajiban untuk selalu siaga dan ikut serta dalam usaha pencegahan dan penanggulangan serta pemadaman kebakaran hutan dan lahan, baik secara perorangan muapun secara kelompok. Hanya saja pengendalian yang dilakukan masyarakat belum ada.

Pencegahan dan pengendalian kebakaran hutan dan lahan pada areal perusahaan perkebunan/ kehutanan relatif lebih mudah. Aturan pelaksanaan telah jelas sehingga segala bentuk penyimpangan akan relatif lebih mudah dikontrol dan pemberian sanksi dapat diterapkan dengan lebih tegas dibandingkan dengan kebakaran yang terjadi di lahan milik penduduk dan lahan pertanian masyarakat yang terlantar. Hal mana akan lain bagi 
masyarakat/ peladang berpindah yang telah terbiasa membuka lahan dengan cara membakar, mereka tidak memilki alternatif lain dalam membuka lahannya, sehingga masyarakat/ peladang berpindah akan tetap menggunakan api dalam setiap penyiapan lahan untuk kegiatan pertaniannya. Melihat kondisi tersebut karenanya peran serta masyarakat dalam hal ini sangat diperlukan.

Peran serta masyarakat dalam pencegahan dan penanggulangan kebakaran lahan di Desa Seling Tabir tidaklah dapat serta merta dipisahkan dengan sistem pertanian mereka. Kondisi tersebut bertentangan dengan ayat 2 Pasal 17 Peraturan Bupati Merangin Nomor 12 Tahun 2016 Tentang Sistem Pengendalian Kebakaran Hutan dan Lahan yang berbunyi bahwa setiap orang yang mengetahui adanya api yang berada dihutan dan/atau lahan yang patut diduga dapat mengakibatka timbulnya kebakaran, wajib segera melaporkan kepada aparat pemerintah daerah terdekat.

Selanjutnya Ayat 5 menjelaskan apabila terjadi kebakaran hutan dan lahan, pemilik usaha perkebunan dan pemilik lahan segera mengambil tindakan yang perlu untuk mencegah meluasnya kebakaran hutan dan lahan, kemudian melaporkan kepada aparat pemerintah daerah terdekat.

3. Penanggulangan Kebakaran Hutan dan Lahan

Pasal 20 Peraturan Bupati Merangin Nomor 12 Tahun 2016 Tentang Sistem Pengendalian Kebakaran Hutan dan Lahan menyatakan upaya penanggulangan kebakaran hutan dan lahan dilakukan secara sistematis, terpadu, menyeluruh, dan tuntas dengan melibatkan semua pemangku kepentingan, dalam hal terjadi kebakaran hutan dan lahan yang memerlukan penanganan segera di wilayah kecamatan, maka camat melakukan upaya pemadaman, camat wajib melaporkan kepada Bupati tentang kejadian kebakaran hutan dan lahan dan upaya penanggulangan yang dilakukan paling lambat 1 hari setelah diketahui kebakaran hutan lahan.

Pasal 21 menjelaskan dalam hal terjadi kebakaran hutan dan lahan pada lintas desa da atau lintas kecamatan, camat wajib melakukan koordinasi dengan Satgas Dalkarhutla Kabupaten. Kenyataan yang terjadi berbeda dengan peraturan tersebut. Pasal 22 mengamanatkan agar setiap orang/badan usaha/pemilik lahan yang melihat atau mengalami kebakaran segera melaporkan kepada kepala Desa/Lurah atau camat setempat, namun yang terjadi dimasyarakat adalah keengganan untuk melaporkan kejadian yang mereka alami. Upaya pemadaman yang dilakukan masyarakat tersebut telah sesuai dengan ketentuan yang diatur dalam Pasal 22 Ayat 3 yang menyatakan bahwa pemilik lahan dan lapisan masyarakat disekitar kejadian kebakaran hutan dan lahan dapat langsung melakukan pemadaman kebakaran hutan dan lahan.

4. Penanganan Pasca Kebakaran Hutan dan Lahan

Pasal 23 ayat 1 Peraturan Bupati Merangin Nomor 12 Tahun 2016 Tentang Sistem Pengendalian Kebakaran Hutan dan Lahan menyatakan bahwa untuk mengetahui penyebab kabakaran hutan dan lahan serta tingkat kerusakan yang terjadi akibat kebakaran hutan dan lahan perlu dilakukan identifikasi untuk penegakan hukum dan rehabilitasi areal bekas kebakaran.

5. Peningkatan Kesadaran Masyarakat

Pasal 25 Peraturan Bupati Merangin Nomor 12 Tahun 2016 Tentang Sistem Pengendalian Kebakaran Hutan dan Lahan menyatakan bahwa untuk Satgas Dalkarhutla bersama SKPD terkait perlu meningkatkan kesadaran masyarakat mengenai hak dan tanggung jawab serta kemampuannya untuk mencegah kebakaran hutan dan lahan.

Hasil wawancara menunjukan bahwa tingkat kesadaran masyarakat masih rendah dan belum ada upaya yang maksimal dari BPBD Merangin untuk 
meningkatkan partisipasi masyarakat dalam pengendalian kebakaran hutan dan lahan.

Masyarakat telah berupaya untuk melakukan pembakaran terkendali dan menghasilkan sedikit asap lebih dikarenakan aspek ekonomi, yaitu takut terhadap aturan terutama denda dan kecepatan waktu tanam saja. Menghindari denda lebih dikarenakan kekurangmampuan finansial masyarakat, sehingga jika membakar yang dilakukan sampai menimbulkan merembetnya api ke lahan tetangganya hingga harus membayar denda maka pembakaran bukan lagi hal yang murah. Oleh karena itu, yang dilakukan petani saat membakar akhirnya sangat hati-hati dan menjaga lahan yang dibakar dan meninggalkan lahan setelah api benar-benar padam. Sedangkan alasan membakar dengan sedikit asap lebih karena supaya pembakaran cepat sehingga cepat tanam. Pembakaran yang memerlukan waktu lama maka diperlukan sumberdaya yang banyak sehingga masyarakat akan membakar setelah bahan bakaran telah kering benar. Kondisi ini bukan dengan tujuan supaya menghasilakn sedikit asap namun lebih didasarkan supaya cepat selesai, sehingga cepat pula tanamnya.

Hasil pengamatan di lapangan, upaya pencegahan yang dilakukan masyarakat lebih berkembang jika dibandingkan dengan upaya penanggulangan kebakaran lahan itu sendiri. Upaya pemerintah yang lebih menekankan penanggulangan kebakaran lahan melalui pembentukan kelompok peduli api sepertinya kurang dapat direspon masyarakat, hal tersebut dikarenakan pemadaman memerlukan biaya dan tenaga yang tidak sedikit, kegiatan pemadaman merupakan kegiatan yang tidak nyaman dan melelahkan serta kegiatan yang banyak menyita waktu serta bersifat sukarela atau kegiatan tanpa insentif

Dalam kegiatan penanggulangan kebakaran lahan, peran serta masyarakat sangat dibutuhkan. Hal tersebut dilakukan karena kebakaran akan dapat menyebabkan musnahnya investasi yang telah mereka usahakan, baik tanaman semusim maupun tanaman tahun yang diusahakan. Masyarakat samasama merasakan bagaimana jika kehilangan barang yang berharga, sehingga penanggulangan kebakaran lahan merupakan suatu tanggung jawab bersama. Semangat gotong-royong untuk melokalisir menjalarnya api ke lahan pertanian diupayakan secara bersama, semangat yang masih dijumpai pada kelompok petani Desa Seling Kecamatan Tabir. Berupaya bersama untuk menyelamatkan aset yang ada, namun demikian sikap masyarakat akan berbeda apabila yang terbakar adalah bawas atau lahan tidur. Upaya pemadaman hany a dilakukan pada lahan pertanian yang berpotensi saja sedangkan pada lahan tidur atau lahan yang tidak berpotensi masyarakat akan membiarkan saja.

Hambatan-hambatan dalam implementasi Peraturan Bupati Merangin Nomor 12 Tahun 2016 Tentang Sistem Pengendalian Kebakaran Hutan dan Lahan di Desa Seling Kecamatan Tabir Kabupaten Merangin

1. Rendahnya kesadaran masyarakat

Rendahnya kesadaran masyarakat merupakan faktor penghambat dalam implementasi Peraturan Bupati Merangin Nomor 12 Tahun 2016 Tentang Sistem Pengendalian Kebakaran Hutan dan Lahan di Desa Seling, karena kesadaran masyarakat untuk tidak melakukan pembakaran adalah kunci keberhasilan dalam mencegah kebakaran hutan dan lahan.

Kondisi tersebut menggambarkan bahwa upaya pencegahan yang dilakukan masyarakat lebih berkembang jika dibandingkan dengan upaya penanggulangan kebakaran lahan itu sendiri. Upaya pemerintah yang lebih menekankan penanggulangan kebakaran lahan melalui pembentukan kelompok peduli api sepertinya kurang dapat direspon masyarakat, hal 
tersebut dikarenakan pemadaman memerlukan biaya dan tenaga yang tidak sedikit, kegiatan pemadaman merupakan kegiatan yang tidak nyaman dan melelahkan serta kegiatan yang banyak menyita waktu serta bersifat sukarela atau kegiatan tanpa insentif

Kepentingan pencegahan dan penanggulangan kebakaran lahan yang ada saat ini masih lebih didominasi oleh keinginan pemerintah. Pencegahan di masyarakat sendiri telah tumbuh dan berkembang, tumbuh karena adanya kepentingan yang sama yaitu kepentingan agar tidak mengganggu milik orang lain. Pencegahan lebih efektif dilakukan masyarakat karena telah adanya kesepakatan dan aturan yang diterapkan oleh masyarakat petani itu sendiri.

Fakta di lapangan, masyarakat lebih "takut" atau menghormati aturan lokal yang telah dibuat. Berkurangnya angka kejadian kebakaran lahan yang bersumber dari merembetnya api dari kegiatan pembukaan lahan dengan cara bakar adalah bukti nyata. Potensi inilah yang tidak mendapat perhatian pemerintah, yang digunakan sebagai dasar pembentukan Kelompok Peduli Api. Namun demikian hasil pengamatan peneliti, hal yang perlu menjadi perhatian adalah bahwa masyarakat masih menganggap pembukaan lahan dengan cara di bakar belum menjadi masalah baik terhadap kesehatan maupun lingkungan hidup.

Pelibatan masyarakat dalam upaya pencegahan kebakaran hutan dan lahan (karhutla), terus dilakukan BPBD Kabupaten Merangin. Masyarakat yang berada di sekitar hutan menjadi aktor utama dalam upaya pencegahan karhutla, karena kesadaran masyarakat untuk tidak melakukan pembakaran adalah kunci keberhasilan dalam mencegah kebakaran hutan dan lahan.

Sedangkan untuk peran serta masyarakat termuat dalam pasal 25 ayat 1 Peraturan Bupati Merangin Nomor 12 Tahun 2016 Tentang Sistem Pengendalian Kebakaran Hutan dan Lahan yaitu : Satgas Dalkarhutla bersama SKPD terkait, perlu meningkatkan kesadaran masyarakat mengenai hak dan tanggung jawab serta kemampuannya untuk mencegah kebakaran hutan dan lahan.

Ayat 2 menjelaskan bahwa peningkatan kesadaran masyarakat sebagaimana dimaksud pada ayat (1) dapat dilakukan dengan mengembangkan nilai-nilai adat serta kebiasaan masyarakat tradisional yang mendukung perlindungan hutan dan lahan.

Untuk menumbuh-kembangkan peran serta masyarakat dalam kegiatan pengendalian kebakaran hutan, dilakukan dalam bentuk : pendidikan dan latihan, Penguatan kelembagaan, Fasilitasi, dan Penyuluhan. Pada dijelaskan bahwa : Peran serta masyarakat dalam kegiatan pengendalian kebakaran hutan dilakukan bersama-sama dengan Brigdalkarhut pada setiap jenjang. Bentuk peranserta masyarakat dilakukan melalui peningkatan kemampuan dan kemandirian dalam kegiatan pengendalian kebakaran hutan.

Peran serta masyarakat yang berkaitan dengan pengendalian kebakaran hutan dan lahan diatur dalam Pasal 46 PP No. 4 Tahun 2001 yaitu "setiap orang mempunyai hak untuk berperan dalam rangka pengendalian kerusakan dan atau pencemaran lingkungan hidup yang berkaitan dengan kebakaran hutan dan atau lahan sesuai dengan peraturan perundang-undangan yang berlaku. Dalam penjelasannya disebutkan bahwa "Peran yang dimaksud meliputi peran dalam proses pengambilan keputusan, baik dengan mengajukan keberatan, maupun dengar pendapat atau dengan cara lain yang ditentukan dalam peraturan perundang-undangan.

Peran tersebut dilakukan antara lain dalam proses penilaian analisis mengenai dampak lingkungan hidup atau perumusan kebijakan pengendalian kerusakan dan atau pencemaran lingkungan hidup yang berkaitan dengan 
kebakaran hutan dan atau lahan. Pelaksanaannya didasarkan pada prinsip keterbukaan. Dengan keterbukaan dimungkinkan masyarakat ikut memikirkan dan memberikan pandangan dan pertimbangan dalam pengambilan keputusan pengendalian kerusakan dan atau pencemaran lingkungan hidup yang berkaitan dengan kebakaran hutan dan atau lahan.

Berdasarkan penjelasan pasal tersebut, peran serta masyarakat lebih di tekankan pada partisipasinya dalam proses perumusan atau pengambilan keputusan kebijakan, yaitu hanya sebatas memberikan saran, pandangan, dan pendapat atau pertimbangan saja. Sedangkan kewenangan pengambilan keputusan sepenuhnya tetap berada di tangan Pemerintah. Pencegahan kebakaran hutan dan lahan merupakan salah satu komponen pengendalian kebakaran hutan yang mencakup semua cara untuk mengurangi atau meminimumkan jumlah kejadian kebakaran liar, bukan menghilangkan semua kejadian kebakaran liar.

2. Mahalnya biaya buka lahan dengan alat berat.

Mahalnya biaya buka lahan dengan alat berat menjadi kendala dalam menerapkan Peraturan Bupati Merangin Nomor 12 Tahun 2016 Tentang Sistem Pengendalian Kebakaran Hutan dan Lahan, maka masyarakat lebih memilih untuk membuka lahan dengan cara membakar. Dampak karhutla akan mengganggu aktivitas manusia. Termasuk berpengaruh kepada kualitas air. Ketika karhutla terjadi, abu turun ke sungai membuat air sungai meskipun hanya digunakan untuk mencuci muka, akan menimbulkan rasa pedih luar biasa, ikan yang ada di sungai pun sekarat.

Bapak Ismail tak menampik jika metode membakar lahan akan menambah unsur hara yang dibutuhkan oleh tanah. Namun menurutnya, lahan yang dibakar pun kalau tak dibantu dengan pupuk ekstra juga akan menurun produksinya. Biaya yang dikeluarkan pada akhirnya juga akan sama mahalnya.

Tidak hanya mencegah kembali terjadinya kebakaran hutan dan lahan, saat ini cukup banyak pihak yang berupaya meningkatkan kesadaran masyarakat dalam melestarikan lingkungan termasuk memberdayakan dan mengolah hasil alam dengan cara ramah lingkungan. Misalnya berupaya mengedukasi dan mendorong masyarakat untuk membuka lahan lahan tanpa bakar dan mengolah lahan pertanian dengan cara yang lebih ramah lingkungan. Untuk tahap awal memang cukup berat mengarahkan masyarakat menggunakan cara ramah lingkungan dalam mengolah lahan, karena selain memerlukan biaya yang cukup banyak, waktu yang digunakan untuk membuka lahan secara manual dan ramah lingkungan juga lebih lama.

Kebakaran hutan dan lahan di Indonesia meningkat selama sepuluh tahun terakhir ini, sebagian besar disebabkan oleh ulah manusia (yang disengaja atau karena lalai) juga karena kondisi yang sangat kering sebagai pengaruh terjadinya perubahan iklim global/makro yang melanda wilayah Indonesia. Kebakaran hutan menjadi ancaman tersendiri bagi negara yang bersangkutan maupun dunia secara umum. Telah dipahami bahwa hutan memegang peranan yang penting bagi keseimbangan hidup di bumi. Rusaknya hutan akan berdampak pada keberlangsungan semua makhluk hidup termasuk manusia. Oleh sebab itu, kelestarian hutan bukanlah sebuah pilihan tetapi sebuah keharusan.

Angka statistik menunjukkan adanya fakta bahwa areal hutan hari demi hari semakin berkurang. Salah satu penyebabnya adalah kebakaran, baik itu yang terjadi secara alamiah maupun karena ulah manusia yang sedang membuka hutan/lahan untuk usaha pertanian ataupun perkebunan. Langkah penanggulangan kerusakan dan kebakaran hutan tentunya jangan membuka lahan/hutan untuk keperluan pertanian/perkebunan dengan cara dibakar. Bila hal ini tetap dilakukan bukan hal yang tak mungkin kelak bumi bukan lagi 
planet yang nyaman untuk dihuni manusia tetapi menjadi bumi yang panas membara.

Dalam Undang-Undang Nomor 18 Tahun 2004 pasal 26 tentang Perkebunan, juga telah diamanatkan bahwa "setiap pelaku usaha perkebunan dilarang membuka dan/atau mengolah lahan dengan cara pembakaran yang mengakibatkan terjadinya pencemaran dan kerusakan fungsi lingkungan". Pekerjaan dan alat yang dipergunakan serta teknis pelaksanaan dalam pembukaan lahan tergantung pada kerapatan vegetasi dan cara yang digunakan.

Untuk membuka lahan tanpa bakar pada areal hutan/semak belukar, hampir sama dengan cara pembukaan lahan tanpa bakar pada areal peremajaan kelapa sawit. Pekerjaan dan alat yang dipergunakan serta teknis pelaksanaannya tergantung pada kerapatan vegetasi dan cara yang digunakan. Ada tiga cara membuka lahan pada areal belukar yaitu cara manual, mekanis dan kombinasi antara manual-mekanis-khemis.

Cara manual, yaitu kegiatan pembukaan lahan dengan tahapan sebagai berikut: 1) Membabat rintisan yaitu memotong dan membabat vegetasi dengan menggunakan parang; 2) Menebang dan merencek (mencincang) batang kayu yang besar dengan menggunakan parang, kapak atau gergaji; 3) Membuat pancang jalur, yaitu jalur tanam yang dibuat menurut jarak antar barisan tanaman, yang dimaksudkan untuk memudahkan pembersihan jalur tanam; 4) Membersihkan jalur tanam, yaitu membersihkan hasil rencekan yang ditempatkan di antara jalur tanaman dengan jarak 1 meter di kiri-kanan pancang, sehingga didapatkan jalur yang bersih dari potongan kayu-kayuan.

Cara mekanis, cara ini dilakukan untuk areal yang memiliki topografi datar dan berombak. Cara penebangan umumnya dilakukan dengan traktor dengan tahapan sebagai berikut: 1) Membabat rintisan, yaitu membabat semak dan kayu yang mempunyai ketinggian $40 \mathrm{~cm}$; 2) Menebang, yaitu menebang pohon yang besar maupun yang kecil dengan menggunakan traktor. Penebangan sebaiknya dengan diikuti penumbangan pohon berikut akarnya. Pohon ditebang ke arah luar agar tidak menghalangi jalannya traktor; 3) Merencek, dilakukan dengan memotong dan mencincang (merencek) cabang dan ranting pohon yang telah ditebang; 4) Membuat pancang jalur yang dibuat menurut arah antar barisan tanaman yang dimaksudkan untuk memudahkan pembersihan jalur tanam; 5) Membersihkan jalur tanam, dengan membuang hasil rencekan batang/pohon dan ditempatkan pada lahan di antara jalur tanaman dengan jarak 1 meter di kiri-kanan pancang.

Cara kombinasi antara manual-mekanis-khemis, cara ini dapat dikombinasikan dengan cara khemis melalui pemanfaatan herbisida pada saat pembukaan lahan perkebunan maupun saat penanaman melalui penyemprotan semak belukar dengan menggunakan paraquat, triasukfuron, gilifosfat maupun jenis bahan kimia lainnya. Dengan memperhatikan aspek kesehatan serta lingkungan dan dalam penggunaannya dilaksanakan dengan bijaksana sesuai dengan petunjuk yang diberikan.

Belum adanya solusi yang jitu dari Pemerintah Daerah Kabupaten Merangin membuat masyarakat enggan mengubah perilaku masyarakat Desa Seling dalam membuka lahan perkebunan dengan cara membakar, dikarenakan lamanya proses tersebut.

Pernyataan tersebut menggambarkan bahwa ada dua solusi yang diberikan Pemerintah Daerah Kabupaten Merangin kepada masyarakat Desa Seling yang ingin membuka lahan dengan cara tanpa membakar, hanya saja solusi tersebut belum mampu mengubah perilaku masyarakat desa Seling, kondisi ini dikarenakan solusi yang ditawarkan oleh Pemerintah Daerah Kabupaten Merangin memerlukan 
biaya mahal yakni menggunakan alat berat, sedangkan jika membiarkan pohon lapuk secara alamiah tentunya membutuhkan waktu yang lama.

\section{Penutup}

Kesimpulan dari penelitian ini adalah 1) Implementasi Peraturan Bupati Merangin Nomor 12 Tahun 2016 Tentang Sistem Pengendalian Kebakaran Hutan dan Lahan belum sepenuhnya diterapkan: a. Belum terbentuknya Regu Darkarhutla sebagai perwujudan struktur organisasi dan prosedur pengendalian; b. pencegahan kebakaran hutan dan lahan; c. penanggulangan kebakaran hutan dan lahan; d. penanganan pasca kebakaran hutan dan lahan; e. peningkatan kesadaran masyarakat penerapan. 2) Hambatan-hambatan dalam implementasi Peraturan Bupati Merangin Nomor 12 Tahun 2016 tentang Sistem Pengendalian Kebakaran Hutan dan Lahan di Desa Seling Kecamatan Tabir Kabupaten Merangin diantaranya a. rendahnya kesadaran masyarakat; b. mahalnya biaya buka lahan dengan alat berat; c. tidak adanya solusi yang tepat untuk membuka lahan perkebunan tanpa harus membakar.

Saran dari penulis adalah 1)Diharapkan partisipasi aktif dari masyarakat Desa Seling Kecamatan Tabir Kabupaten Merangin untuk mencegah kebakaran hutan dan lahan, karena kesadaran masyarakat untuk tidak melakukan pembakaran adalah kunci keberhasilan dalam mencegah kebakaran hutan dan lahan. 2) Diharapkan sikap tegas dari aparat untuk menindak pelaku pembakaran hutan dengan memberikan edukasi terlebih dahulu melalui sosialisasi, sehingga penegakan hukum jadi lebih efektif. 3) Diharapkan dapat terbentuk Regu Darkarhutla di Desa Seling agar pencegahan kebakaran hutan dan lahan dapat dilaksanakan dengan baik.

\section{Referensi}

Abdullah, Rozali.(2005). Pelaksanaan Otonomi Luas Dengan Pemilihan Kepala Daerah Secara Langsung. PT.Raja Grafindo Persada

Asnawi. (2016). Pengetahuan Dasar Pengendalian Kebakaran Hutan.

Manan, Bagir. (2004). wewenang Provinsi, Kabupaten dan Kota dalam Rangka Otonomi Daerah. Manan, Bagir. (2005). Menyongsong Fajar Otonomi Daerah. Penerbit Pusat Studi Hukum.

Moleong, L. J. (2004). Metodologi Penelitian Kualitatif. PT Remaja Rosdakarya.

Nawawi, Hadari, (1992). Metode Penelitian Bidang Sosial. Gajah Mada. University Press.

Nitibaskara, Tubagus Ronny Rahman. (2002). Paradoksal Konflik dan otonomi Daerah, Sketsa bayang-bayang Konflik Dalam Prospek Masa Depan Otonomi Daerah.

Penjelasan Atas Undang-Undang Republik Indonesia Nomor 23 Tahun 2014 Tentang Pemerintahan Daerah

Peraturan Bupati Merangin Nomor 12 Tahun 2016 Tentang Sistem Pengendalian Kebakaran Hutan dan Lahan

Rasyid, F. (2014). Permasalahan dan dampak kebakaran hutan. Jurnal Lingkar Widyaiswara, 1(4), 47-59.

Safe'i, R., Wulandari, C., \& Kaskoyo, H. (2019). Penilaian kesehatan hutan pada berbagai tipe hutan di Provinsi Lampung. Jurnal Sylva Lestari, 7(1), 95-109.

Sri Nurhayati, Q. (2014). Kajian Singkat Terhadap Isu-Isu Terkini Kebijakan Penanganan Kebakaran Hutan Dan Lahan. Info Singkat Kesejahteraan Sosial.

Undang-Undang Nomor 23 Tahun 2014 Tentang Pemerintahan Daerah

Widjaja, HAW. (2005). Penyelenggaraan Otonomi di Indonesia, Raja Grafindo Persada 